\title{
SUSTAINABLE ASSESSMENT OF RETAINING WALLS THROUGH AN ACTIVE LEARNING METHOD CONSIDERING MULTIPLE STAKEHOLDERS
}

\author{
LEONARDO SIERRA-VARELA ${ }^{1}$, VICTOR YEPES ${ }^{2}$, and EUGENIO PELLICER ${ }^{3}$ \\ ${ }^{l}$ Dept of Civil Engineering, Universidad de La Frontera, Temuco, Chile \\ ${ }^{2}$ ICITECH, Universitat Politècnica de València, Valencia, Spain \\ ${ }^{3}$ School of Civil Engineering, Universitat Politècnica de València, Valencia, Spain
}

\begin{abstract}
The sustainability approach has changed the modern society. Currently, the sustainability takes into consideration, not only the economic and environmental facets, but also the social facet. Taking into account the three facets of sustainability, this paper shows the application of a method of active learning to assess the sustainability of three real retaining walls. A group of 29 students of the Master of Science in Planning and Management in Civil Engineering at the Universitat Politècnica de València has experienced this assessment. The method followed was proposed by academics of the School of Civil Engineering of the Universitat Politècnica de València (Spain) and Universidad de La Frontera (Chile). An approach multi-criteria and a clusters analysis are part of method, which allows developing a participative process with different points of view about the sustainability. The outcomes show that of this way students can forecast impacts from of the integration of design, planning and the location context of the infrastructure. Result evidence that personal values of each student influences the election of the optimal alternative. The paper also identifies the need to strengthen the conceptualization of social criteria in the students training.
\end{abstract}

Keywords: Infrastructure, Education, Cluster analysis, Analytic hierarchy process, Civil engineering, Sustainability.

\section{INTRODUCTION}

In the last decade, there has been growing interest for the integration of sustainability into the university curricula. Nonetheless, sustainability is a recent idea in modern society, which has not adequately permeated all university strata yet (Lozano and Young 2013). Sustainability is composed of three equally important elements: social, economic and environmental. However, Brown et al. (2015) state that professionals understand sustainability of different way according to its knowledge, training and personal beliefs. In fact, Wright and Wilton 2012 affirm that sustainability is considered in higher education mainly focused on the environment. In addition, Byrne et al. (2013) indicate that engineering professionals associate certain concepts with sustainability according to their education in the past. In this sense, new active-learning methods are necessaries, which consider the value judgments on the integral sustainability through practical experiences and participation techniques (Sieffert et al. 2014). 
An active-learning method has been proposed by academics of the Schools of Civil Engineering of Universitat Politècnica de València (Spain) and Universidad de La Frontera (Chile) to assess the sustainability of infrastructures in collaborative teams (Pellicer et al. 2016). This method provides for supporting sustainability conceptualization, decision-making in uncertain contexts and collaborative work of the students. Specifically, the learning outputs of this method focus in three aspects: (1) the appropriate interpretation of the integral sustainability criteria; (2) the identification of project characteristics that affect sustainability; and (3) the understanding of how preferences regarding sustainability influence the final decision-making process. The assessment starts with the identification of students' profiles regarding sustainability. This is done by using the analytic hierarchy process (AHP hereafter); according to the comparison of the importance, each student places on the sustainability criteria. A cluster analysis identifies the student profiles according to the distance between their preferences. The profiles represent the stakeholder's interests in the prioritization of an infrastructure. This way, the students' views of sustainability can be grouped and obtain the weight according to every of the selected criteria. Then, based on the chosen criteria and indicators the students must appraise the alternative infrastructures. According to the weight of each profile and the appraisal of the infrastructure alternatives, the prioritization is obtained. Finally, a sensitivity analysis shows how the outcome can be affected in light of a possible variation of student profile.

Thus, an active-learning method can improve the understanding of sustainability (Byrne et al. 2013, Sieffert et al. 2014) by means of the challenge of the evaluation of the infrastructure (Pellicer et al. 2016). This paper presents a case study of the implementation of the active learning method proposed by Pellicer et al. (2016), for the assessment of the sustainability of retaining walls by graduate students. The communication begins with an explanation of the background of the case study. Next, the key points of the implementation of the method are exposed. Finally, results are discussed and conclusions presented.

\section{BACKGROUNDS}

Graduate students enrolled in the Project Feasibility course (2015) put the active-learning method into practice. This course is part of the Master of Planning and Management in Civil Engineering at the Universitat Politècnica de València (Spain). The MSc degree applies a holistic managerial approach to construction from both production and business standpoints (Yepes et al. 2012; Torres-Machí et al. 2013). Table 1 shows the characterization of the students.

Table 1. Background of the students of Project Feasibility course 2015.

\begin{tabular}{|c|c|c|c|c|c|c|}
\hline \multicolumn{2}{|c|}{ Number of students } & 29 & \multirow{4}{*}{$\begin{array}{l}{[1-4]} \\
{[4-7]} \\
{[7-10]} \\
{[10 \text { and more }]}\end{array}$} & & \multicolumn{2}{|l|}{$44.8 \%$} \\
\hline \multirow[t]{4}{*}{ Age } & \multirow{4}{*}{$\begin{array}{l}{[20-23]} \\
{[24-28]} \\
{[28-32]} \\
{[32-36]} \\
{[36-39]}\end{array}$} & \multirow{4}{*}{$\begin{array}{c}6.9 \% \\
41.4 \% \\
41.4 \% \\
6.9 \% \\
3.4 \% \\
\end{array}$} & & & \multirow{3}{*}{\multicolumn{2}{|c|}{$\begin{array}{c}41.4 \% \\
10.3 \% \\
2.9 \% \\
\end{array}$}} \\
\hline & & & & & & \\
\hline & & & & & & \\
\hline & & & $\begin{array}{l}\text { Sustainability: } 1 \text { environmental, } \\
2 \text { economic and } 3 \text { social. }\end{array}$ & 1 & 2 & 3 \\
\hline \multirow[t]{3}{*}{ Origin } & Europe & $34.6 \%$ & Part of a course & 21 & 17 & 17 \\
\hline & Americas & $62.0 \%$ & Full course & 1 & 1 & 1 \\
\hline & Africa & $3.4 \%$ & No training & & $17.2 \%$ & \\
\hline \multirow[t]{2}{*}{ Sex } & Male & $62.1 \%$ & Experience & 11 & 2 & 3 \\
\hline & Female & $37.9 \%$ & No & & $55.2 \%$ & \\
\hline \multirow[t]{4}{*}{ Profession } & Civil Engineer & $79.3 \%$ & & & & \\
\hline & Architect & $3.5 \%$ & & & & \\
\hline & Construction Eng. & $10.3 \%$ & & & & \\
\hline & Building Engineer & $6.9 \%$ & & & & \\
\hline
\end{tabular}


The students developed a case study that considers the life-cycle assessment (construction and operation) of two alternatives of retaining walls located in urban contexts. Similar studies have been undertaken with respect to evaluations in retaining walls (Molina-Moreno et al. 2017, Zastrow et al. 2017). In this case, the alternatives are located in mid-sized towns (around 15,000 people) of the Regions of Andalucía and Comunidad Valenciana (Spain). The main characteristics of both alternatives are explained below:

(i) Alternative M1 (Figure 1a): Project the retaining wall of $118 \mathrm{~m}$ long with a deadline of 5 months and an estimated hiring of 28 people. During construction, the public services of electrification, potable water and sewage need to be intervened. The value of bidding is $€ 252,129$, and health and safety costs are allocated to a $1.05 \%$. This is pigmented concrete finish, in line with the urban regulations of the residential area. Two hundred and eighty three people were direct beneficiaries of the project in the short-term.

(ii) Alternative M2 (Figure 1b): Project the retaining wall of $86 \mathrm{~m}$ in length with a deadline of four months and an estimated hiring of 13 people. During the construction, electrical public services need to be intervened. The value of bidding is $€ 78,476$, and health and safety costs are allocated to a $0.57 \%$. Project the retaining wall of $86 \mathrm{~m}$ in length with a deadline of four months and an estimated hiring of 13 people. During construction, electrical services need to be intervened. The value of bidding reaches $€ 78,476$, with an allocation to health and safety costs of $0.57 \%$. 166 people were direct beneficiaries of the project, short-term.

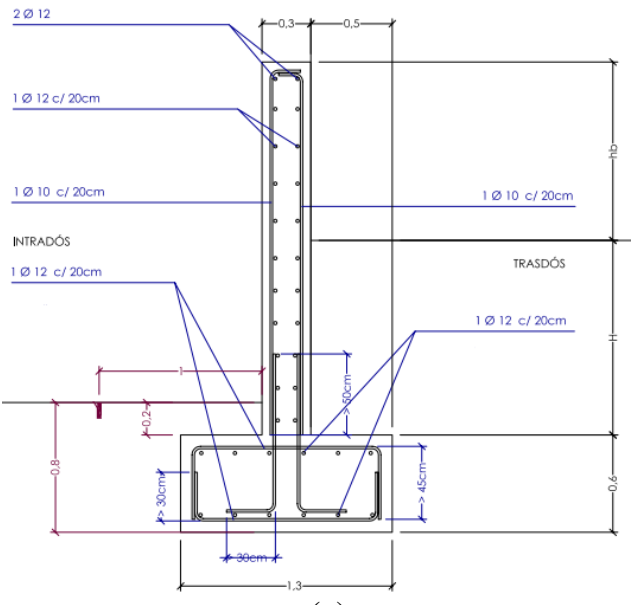

(a)

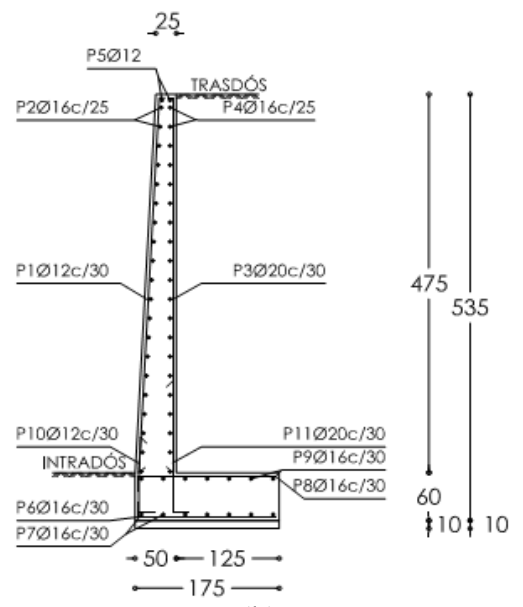

(b)

Figure 1. Sections of the retaining wall alternatives M1 (a) and M2 (b) used as a case study.

\section{METHODS}

The implementation of the proposed method seeks to prioritize a retaining walls project regarding their contribution to sustainability; the students carried out this prioritization. Table 2 represents a breakdown structure in eight steps corresponding to this practical implementation. It is grouped into three stages, using nine classroom hours guided by a teacher. The activity was graded according to a final report for each team. The sustainability criteria stated for Labuschagne et al. (2005) was used in this practical implementation. The sustainability criteria used were:

(i) Economic: Financial Health, Economic Performance, Financial Potential, Trading Opportunities. 
(ii) Environmental: Air Resources, Water Resources, Land Resources, Mined Abiotic Resources.

(iii) Social: Internal Human Resources, External Population, Stakeholder Participation, Macro Social Performance.

Table 2. The participatory process layout.

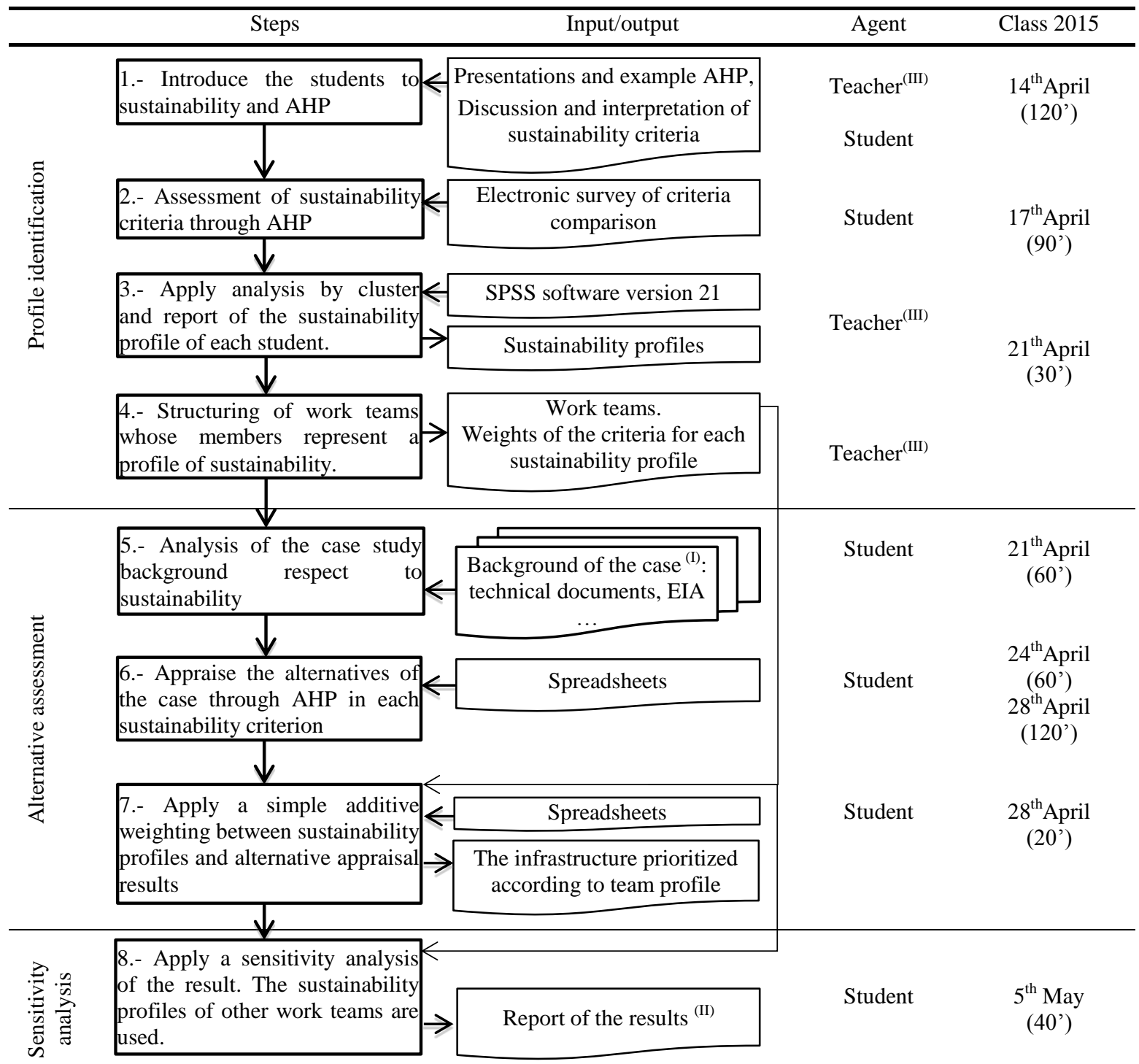

Notes: (I) The background of the case is given to students one week in advance, through virtual platform. The facilitator notifies students the need to review the background. (II) Preparation time results report by the students was a week. (III) The teacher was an instructor specialized in the assessment of construction projects and in sustainability. Two senior professors also supervised him.

\section{RESULTS}

The following sustainability profiles were identified in the study for the 2015 class, according to step three of Table 2: (A) financial, i.e. the student prefers to guarantee funding throughout the 
project life-cycle; (B) environmental; (C) economic, i.e., the student prefers to ensure the economic profitability of the project; and (D) social. According to the sustainability profiles and work teams Table 3 shows the results obtained from step 7 (Table 2). Moreover, Table 3 displays a general sample of arguments according to the chosen infrastructure. Thus, the construction phase of the alternative M1 satisfies the conditions of most of the teams. This has social characteristics (procurement, socioeconomic contributions and citizen involvement) that attracts the preferences of profiles B and D. Furthermore, this fact has associated financial subsidies that attract Profile A. During the operation phase, Profiles A and B prefer Alternative M2 because of its environmental potential and the indirect contribution to the local economy, respectively. On the other hand, the financial profitability and the contribution to the local community of Alternative M1 attract the preference of profiles C and D.

Table 3. Prioritized project for the student teams.

\begin{tabular}{|c|c|c|c|c|c|}
\hline \multirow[t]{2}{*}{ Team } & \multirow{2}{*}{$\begin{array}{c}\text { Team } \\
\text { members' } \\
\text { profiles }\end{array}$} & \multicolumn{2}{|c|}{$1^{\text {st }}$ place / Weight } & \multicolumn{2}{|c|}{ The key considerations that students took into account } \\
\hline & & $\mathbf{C}^{(\mathrm{I})}$ & $\mathbf{O}^{(\mathbf{I})}$ & Alternative M1 & Alternative M2 \\
\hline 1 & $\begin{array}{l}4 \text { members } \\
\text { Profile A }\end{array}$ & M1 (0.54) & M2 (0.62) & \multirow{8}{*}{$\begin{array}{l}\text { - Recruitment in an area with } \\
\text { higher unemployment. } \\
\text { - Use of materials and hiring of } \\
\text { services in the local area. } \\
\text { - The project stems from a } \\
\text { process of public consultation. } \\
\text { - It strengthens an "Urban } \\
\text { Rehabilitation" program with a } \\
\text { - subsidy of } € 151,732 \text {. } \\
\text { - It involves more economic } \\
\text { - movement for a longer period. } \\
\text { - It has a better use of public } \\
\text { - resources given its maintenance } \\
\text { costs and number of } \\
\text { beneficiaries. }\end{array}$} & \multirow{8}{*}{$\begin{array}{l}\text { - It produces a lower volume of solid } \\
\text { waste. } \\
\text { - It does not require an environmental } \\
\text { impact assessment. } \\
\text { - It involves less use of energy and } \\
\text { mineral resources } \\
\text { - Risk of delayed payments } \\
\text { (promoter) is low. } \\
\text { - Risk of non-compliance of financial } \\
\text { commitments (suppliers) is low. } \\
\text { - Maintenance activities are manual } \\
\text { with lower emissions, and reduced } \\
\text { consumption of energy and water. } \\
\text { - It boasts improved accessibility for } \\
\text { the people, safety, and rural tourism. }\end{array}$} \\
\hline 2 & $\begin{array}{c}4 \text { members } \\
\text { Profile A }\end{array}$ & $1(0.55)$ & M2 & & \\
\hline 3 & $\begin{array}{c}4 \text { members } \\
\text { Profile B }\end{array}$ & $\begin{array}{l}\text { M1 (0.50) } \\
\text { M2 (0.50) }\end{array}$ & M2 (0.69) & & \\
\hline 4 & $\begin{array}{l}5 \text { members } \\
\text { Profile B }\end{array}$ & M1 (0.51) & M2 (0.73) & & \\
\hline 5 & $\begin{array}{c}4 \text { members } \\
\text { Profile B }\end{array}$ & M1 (0.52) & M2 (0.52) & & \\
\hline 6 & $\begin{array}{c}4 \text { members } \\
\text { Profile C }\end{array}$ & $\mathrm{M} 2(0.57)$ & M1 (0.53) & & \\
\hline 7 & $\begin{array}{c}1 \text { member } \\
\text { Profile B + } 3 \\
\text { members } \\
\text { Profile D }\end{array}$ & M1 (0.64) & M2 (0.74) & & \\
\hline & & & & & \\
\hline
\end{tabular}

In this case, a sensitivity analysis confirms the influence of the sustainability profile on the prioritization of the infrastructure. When the weight of the criteria was exchanged with the profile $\mathrm{C}$, the prioritization was adjusted to the results shown in Table 3.

It was necessary to clarify the analysis of social sustainability during implementation. In some cases, the difficulty in using qualitative variables or the treatment of social criteria. The importance of graduating the social criteria in the life cycle of infrastructures was recently identified (Sierra et al. 2016). In an educational scenario is important to consider that the students are not experts; therefore, the role of the facilitator is critical for the case study.

\section{CONCLUSIONS}

This paper presents the implementation of a method that improves learning by using a simulated experience for decision-making sustainable, which focuses on the assessment of two retaining walls by graduate student. From this experience, the following conclusions may be derived:

i) Outcomes show that the implemented method can be used as an active-learning method to assess the sustainability of retaining walls. 
ii) The implemented method has a rational and participatory approach that simulates multiple views from construction professionals regarding sustainability.

iii) The students can undertake a critical analysis and to understand how their personal values influence the selection of a project. This context is similar to the real case with multiples stakeholder and different profile, which influence the decisions make sustainable.

iv) Clarifying the learning of the treatment of social sustainability in infrastructures is needed.

Further, the main limitations were the need to train the teacher in sustainability issues and in construction processes, as well as a minimum previous professional experience of the students. Future lines of research could focus on finding active-learning strategies that represent the interaction between the sustainability criteria.

\section{References}

Brown, S., Bornasal, F, Brooks, S., and Martin, J. P., Civil Engineering Faculty incorporation of sustainability in courses and relation to sustainability beliefs, J. of Prof. Issues in Eng. Educ. and Pract., In press, 2015, doi: 10.1061/(ASCE)EI.1943-554.0000225

Byrne, E. P., Desha C. J., Fitzpatrick, J. J., and Hargroves, K., Exploring sustainability themes in engineering accreditation and curricula. Int. J. of Sustain. in High. Educ. 14(4), 384-403, 2013, doi: 10.1108/IJSHE-01-2012-0001.

Labuschagne, C., Brent, A.C., and van Erck, R.P., Assessing the sustainability performances of industries. J. of Clean. Prod. 13. 373-385, 2005, doi: 10.1016/j.jclepro.2003.10.007.

Lozano, R. and Young, W., Assessing sustainability in university curricula: exploring the influence of student numbers and course credits. J. of Clean. Prod. 49, 134-141, 2013, doi: 10.1016/j.jclepro.2012.07.032.

Molina-Moreno, F., Garcia-Segura, T., Marti, J.V., Yepes, V., Optimization of Buttressed Earth-Retaining Walls using Hybrid Harmony Search Algorithms. Eng. Struct., 134, 205-216, 2017, doi: 10.1016/j.engstruct.2016.12.042.

Pellicer, E., Sierra, L., and Yepes, V., Appraisal of infrastructure sustainability by graduate students using an active-learning method. J. Clean. Prod., 113(1), 884-896, 2016 doi: 10.1016/j.jclepro.2015.11.010.

Sieffert, Y., Huygen, J.M., and Daudon, D., Sustainable construction with repurposed materials in the context of a civil engineering-architecture collaboration, J. of Clean. Prod., 67, 125-138, 2014, doi: 10.1016/j.jclepro.2013.12.018.

Sierra, L., Yepes, P., and Pellicer, E., Social sustainability in the life cycle of Chilean public infrastructure. J. Constr. Eng. M. In press. (2016), doi: 10.1061/(ASCE)CO.1943-7862.0001099.6.

Torres-Machi, C., Carrion, A., Yepes, V., and Pellicer, E., Employability of graduate student in construction management. J. of Prof. Issues in Eng. Educ. and Pract., 139(2), 163-170, 2013, doi: 10.1061/(ASCE)EI.1943-5541.0000139.

Wright, T. S. A. and Wilton, H., Facilities management directors' conceptualizations of sustainability in higher education. J. of Clean. Prod., 31, 118-12, 2012, doi: 10.1016/j.jclepro.2012.02.030.

Yepes, V., Pellicer, E., and Ortega, A. J., Designing a benchmark indicator for managerial competences in construction at the graduate level. J. of Prof. Issues in Eng. Educ. and Pract., 138(1), 48-54, 2012, doi: 10.1061/(ASCE)EI.1943-5541.0000075.

Zastrow, P., Molina-Moreno, F., Garcia-Segura, T., Marti, J. V., and Yepes, V., Life cycle assessment of cost-optimized buttress earth-retaining walls: a parametric study, J. Clean. Prod., 140, 1037-1048, 2017, doi: 10.1016/j.jclepro.2016.10.085. 